\title{
The Catalytic Impact of Ethionine on the Multi-Step Electroreduction of Bi(III) Ions in Chlorates(VII) Solutions
}

\author{
Agnieszka Nosal-Wiercińska $^{1} \cdot$ Mariusz Grochowski $^{1}$
}

Published online: 21 July 2017

(C) The Author(s) 2017. This article is an open access publication

\begin{abstract}
It was concluded that the presence and the protonation of the ethionine (Et) have effects on the rate of the multistep process of $\mathrm{Bi}(\mathrm{III})$ electroreduction in the $2 \mathrm{~mol} \mathrm{dm}^{-3}$ chlorates(VII). The catalytic activity of ethionine increases with increasing amounts of $\mathrm{NaClO}_{4}$ in the basic electrolyte solution. Increased amounts of $\mathrm{HClO}_{4}$ in chlorate(VII) solutions causes a decreased rate of the $\mathrm{Bi}(\mathrm{III})$ ion electroreduction process in the presence of ethionine. This confirms the assumption on the variety of active complexes mediating the passage of electrons.
\end{abstract}

Keywords Electrochemistry · Bi(III) electroreduction · Ethionine $\cdot$ Catalytic activity $\cdot$ Standard rate constants

\section{Introduction}

Ethionine is an ethyl analogue of methionine and has a very destructive influence on the livers of living organisms and disrupts the activity of many enzymes. Ethionine interferes with the methionine metabolism, leading to depletion of the primary methyl donor, S-adenosylmethionine [1]. It is a strongly carcinogenic metabolite contributing to the development of most types of human cancer [2].

Agnieszka Nosal-Wiercińska

anosal@ poczta.umcs.lublin.pl

1 Department of Analytical Chemistry and Instrumental Analysis, Faculty of Chemistry, M. Curie-Skłodowska University, M. Curie-Skłodowska Sq. 3, 20-031 Lublin, Poland
Therefore, it is necessary to monitor the level of ethionine and to demonstrate new methods for determination of this amino acid in various environments.

The cap-pair effect opens the door to determination of ions of many depolarisers in weak complexing solutions $[3,4]$ and, indirectly, of catalysing substances.

Studies on the kinetics of various depolarisers in the presence of electrode substances are comprehensively discussed in the literature [5-11]. It was demonstrated that the structures of the inter-phase area caused by adsorption of organic compounds on the surface of mercury play a significant role in the mechanism of the cap-pair effect. A significant role in the catalytic electroreduction of the depolariser is also played by water activity $[12,13]$.

The reversibility of $\mathrm{Bi}(\mathrm{III})$ electroreduction in chlorates(VII) increases with decreasing water activity [14]. It has also been shown that the process of $\mathrm{Bi}(\mathrm{III})$ ion electroreduction is catalysed by methionine [15], cysteine and cystine $[16,17]$. Values of the standard rate constant $k_{s}$ [4] indicate that the catalytic effect of amino acids grows - in the order of cystine $<$ methionine $<$ cysteine - for chlorates(VII) with high water activity (from 1 to $4 \mathrm{~mol} \mathrm{dm}^{-3}$ ). For higher concentrations of chlorates(VII) (from 5 to $8 \mathrm{~mol} \mathrm{dm}^{-3}$ ), the comparable effect of amino acids on the rate of electroreduction of $\mathrm{Bi}(\mathrm{III})$ ions is observed [4]. Also, the significant changes in the kinetics of the $\mathrm{Bi}$ (III) ions electroreduction process and in the presence of homocysteine or homocystine apropos and the change of $\mathrm{HClO}_{4}: \mathrm{NaClO}_{4}$ ratio in the solutions of chlorates(VII) were found [18, 19]. With an increase in the amount of $\mathrm{NaClO}_{4}$ in the basic electrolyte solution, the catalytic activity of both homocysteine and homocystine increases. However, an increase in the amount of $\mathrm{HClO}_{4}$ in chlorate(VII) solutions does not cause significant changes in the kinetics of the Bi(III) ions electroreduction in the presence of these amino acids. 
The mechanism of the catalytic effect of homocysteine and homocystine, which react with mercury electrochemically to form mercury cysteine thiolates, is associated with the formation of active $\mathrm{Bi}-\mathrm{Hg}(\mathrm{SR})_{2}$ complexes which facilitate the electrode process [18, 19].Changes in the relation between the rates of $\mathrm{Bi}(\mathrm{III})$ electroreduction in the presence of ethionine which is polarographically inactive in conditions of its varied protonation were observed.

Such electrochemical methods as DC polarography, SWV voltammetry and cyclic voltammetry (CV), as well as electrochemical impedance spectroscopy were used to study the kinetics and mechanism of the $\mathrm{Bi}$ (III) ions electroreduction and in the presence of ethionine. The following kinetics parameters: formal potential $\left(E_{f}^{0}\right)$, cathodic transition coefficient $(\alpha)$, standard rate constants $\left(k_{s}\right)$ of the depolariser electroreduction and diffusion coefficient $\left(D_{o x}\right)$ will define the size of the catalytic effect and the type of the electrode mechanism. This will also facilitate correlation with changes in the protonation of the catalysing substances.

\section{Experimental}

An electrochemical analyser $\mu$ Autolab (Eco Chemie) controlled by means of the application GpES ver. 4.9 an M164 electrode stand (MTM Anko Instruments) was used for measurements. The measurements were performed in a three-electrode cell containing a dropping or hanging mercury electrode with a controlled increase rate and a constant drop surface $\left(0.014740 \mathrm{~cm}^{2}\right)$, as a working electrode (MTM Poland); $\mathrm{Ag} / \mathrm{AgCl}$ in the $3 \mathrm{~mol} \mathrm{dm}^{-3} \mathrm{KCl}$ (Mineral) as a reference electrode and a platinum spiral, as an auxiliary electrode. Analytical grade chemicals from Fluka were used. Water applied to prepare all solutions was purified in the Millipore system. The $2 \mathrm{~mol} \mathrm{dm}^{-3}$ chlorates(VII) solutions of concentration ratio $\mathrm{HClO}_{4}: \mathrm{NaClO}_{4}:(1: 1)$ solution A, (1:4) solution $\mathrm{B}$, (1:9) solution $\mathrm{C}$, (4:1) solution D and (9:1) solution $\mathrm{E}$ were studied. The change of $\mathrm{pH}$ solutions was not observed with the ratio change of $\mathrm{HClO}_{4}: \mathrm{NaClO}_{4}$. The $\mathrm{pH}$ was about 0 . The solutions were deaerated using nitrogen, which was passed over the solutions during the measurements, at $298 \mathrm{~K}$. The $\mathrm{Bi}(\mathrm{III})$ concentration in the solutions was always $1 \times 10^{-3} \mathrm{~mol} \mathrm{dm}^{-3}$. The concentrations of the ethionine were chosen to be $3 \times 10^{-4}$ and $1 \times 10^{-2} \mathrm{~mol} \mathrm{dm}^{-3}$. The ethionine solutions were prepared immediately before the measurements. In the DC polarography, square - wave and cyclic voltammetry - the optimal experiment operating conditions were as follows: scan rate $2 \mathrm{mV} \mathrm{s}^{-1}$ for DC, pulse amplitude $20 \mathrm{mV}$, frequency $120 \mathrm{~Hz}$ and step potential $2 \mathrm{mV}$ for the SWV, and scan rate 5$1000 \mathrm{mV} \mathrm{s}^{-1}$ and step potential $5 \mathrm{mV}$ for the $\mathrm{CV}$.

\section{Results and Discussion}

As Fig. 1a indicates, the current of SWV peaks of the Bi(III) ions electroreduction increases after introduction of ethionine in $2 \mathrm{~A}, \mathrm{~B}, \mathrm{C} \mathrm{mol} \mathrm{dm}{ }^{-3}$ chlorate(VII) solutions and with an increase in the concentration of the amino acid in the solution. Simultaneously, the width of the peaks decreases to half their height, which indicates an increase in reversibility of the $\mathrm{Bi}(\mathrm{III})$ ions electroreduction in the presence of ethionine. However, for the significantly greater amount of $\mathrm{HClO}_{4}$ in the $2 \mathrm{~mol} \mathrm{dm}^{-3}$ chlorates(VII), after the introduction of ethionine, the height of the peak is comparable, but it is poorly defined. Further increase in the concentration of the amino acid in the basic electrolyte increases the height of the SWV peak of the $\mathrm{Bi}$ (III) ions electroreduction. However, it has to be emphasised that this is a significantly smaller increase in comparison to chlorate(VII) solutions in which the amount of sodium chlorate(VII) prevails.

The presence of ethionine in the studied solutions of basic electrolytes alters the image of the DC polarographic waves of the $\mathrm{Bi}$ (III) ions electroreduction (Fig. 2). A shift in the potential of the $E_{1 / 2}$ half-wave to more positive potentials is observed with a simultaneous increase in their tilt, which indicates an increase in the reversibility of the $\mathrm{Bi}(\mathrm{III})$ ions electroreduction in the $2 \mathrm{~mol} \mathrm{\textrm {dm } ^ { - 3 }}$ chlorates(VII) in the

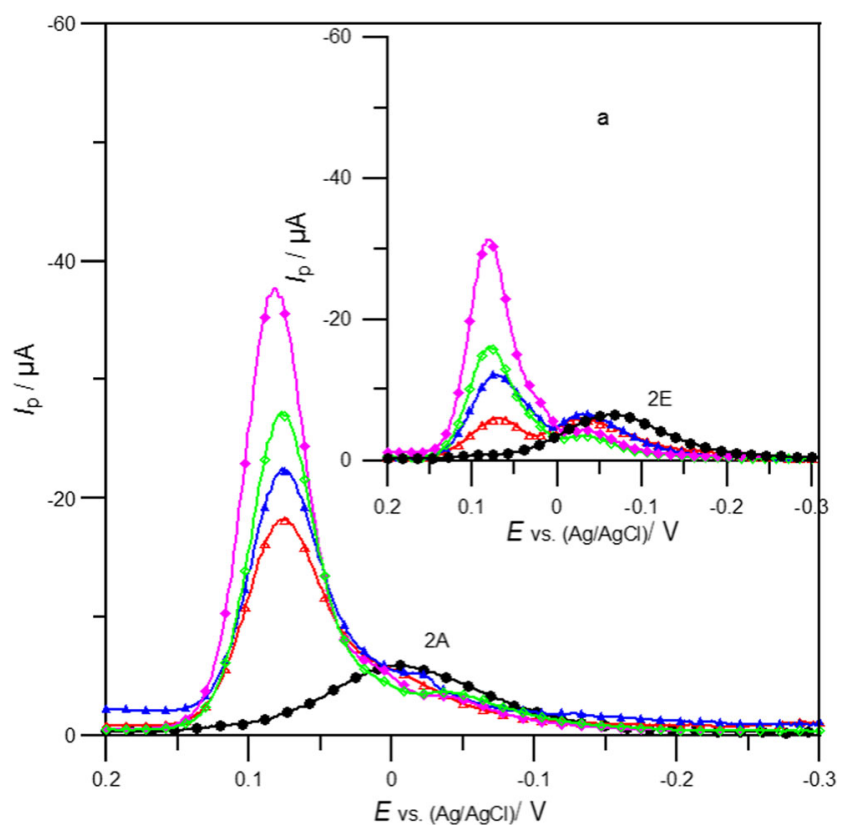

Fig. 1 The SWV peaks of the electroreduction of $1 \times 10^{-3} \mathrm{~mol} \times \mathrm{dm}^{-3}$ $\mathrm{Bi}(\mathrm{III})(-)$ in $2 \mathrm{~mol} \mathrm{dm}^{-3}$ chlorates(VII) in the presence ethionine in $\mathrm{mol} \mathrm{dm}{ }^{-3}: 0(\bullet), 3 \times 10^{-4}(\Delta), 1 \times 10^{-3}(\boldsymbol{\Delta}), 3 \times 10^{-3}(\diamond), 6 \times 10^{-3}(\bullet)$; where $\mathrm{HClO}_{4}: \mathrm{NaClO}_{4}=1: 1$ (A). a The SWV peaks of the electroreduction of $1 \times 10^{-3} \mathrm{~mol} \mathrm{dm}^{-3} \mathrm{Bi}(\mathrm{III})(-)$ in $2 \mathrm{~mol} \mathrm{dm}^{-3}$ chlorates(VII) in the presence ethionine in $\mathrm{mol} \mathrm{dm}^{-3}: 0(\bullet), 3 \times 10^{-4}$ $(\Delta), 1 \times 10^{-3}(\boldsymbol{\Delta}), 3 \times 10^{-3}(\diamond), 6 \times 10^{-3}(\diamond)$; where $\mathrm{HClO}_{4}: \mathrm{NaClO}_{4}=9: 1(\mathrm{E})$ 


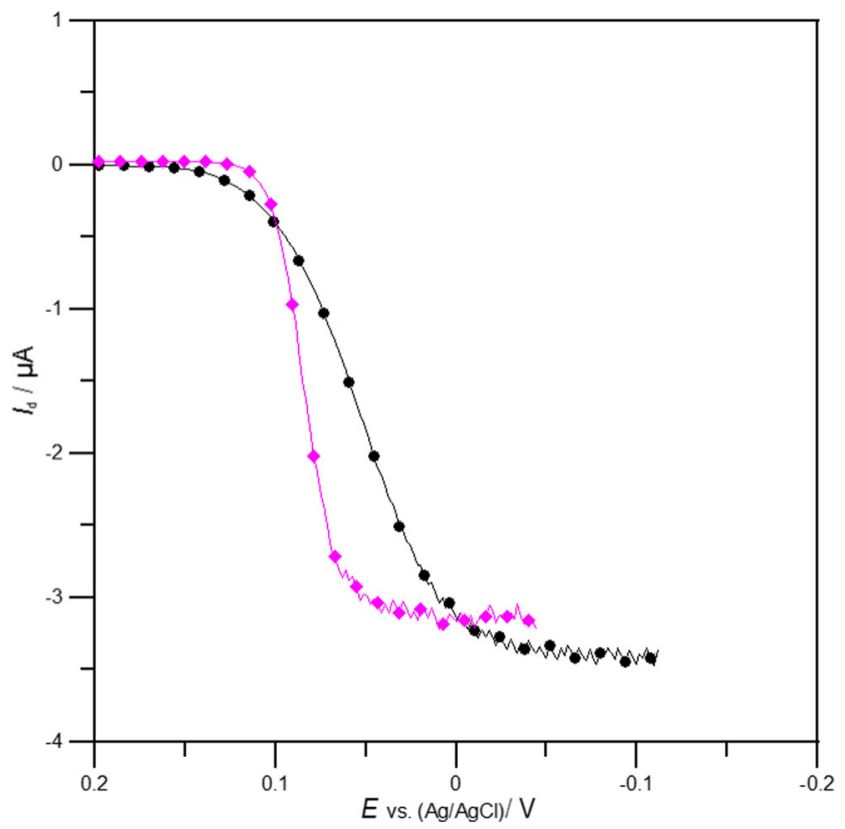

Fig. 2 The DC polarograms of $1 \times 10^{-3} \mathrm{~mol} \mathrm{dm}^{-3} \mathrm{Bi}(\mathrm{III})(\bullet)$ in $2 \mathrm{~mol} \mathrm{dm}^{-3}$ chlorates(VII) and in the presence $6 \times 10^{-3} \mathrm{~mol} \mathrm{dm}^{-3}$ ethionine (»), where $\mathrm{HClO}_{4}: \mathrm{NaClO}_{4}=1: 1(\mathrm{~A})$

presence of ethionine. A slight decrease in the height of the DC waves both after the introduction of the amino acid and with an increase in its concentration in the basic electrolyte is reflected in the determined diffusion coefficients (Table 1).

The influence of ethionine and the changes in the ratio of concentrations $\mathrm{HClO}_{4}: \mathrm{NaClO}_{4}$ on the reversibility of $\mathrm{Bi}(\mathrm{III})$ ion electroreduction also follows from the course of $\mathrm{CV}$ curves (Fig. 3). The presence of $6 \times 10^{-3} \mathrm{~mol} \mathrm{dm}^{-3}$ ethionine results in a decrease of the distance between in the anodic and cathodic peaks $\left(\Delta E_{a c}\right)$ in comparison with the distance registered for the solution of $\mathrm{Bi}(\mathrm{III})$ ions in chlorate(VII), what testifies for the increase of reversibility of $\mathrm{Bi}(\mathrm{III})$ ions electroreduction processes. Moreover, $\Delta E_{a c}$ for the $\mathrm{Bi}$ (III) ions electroreduction in the presence of ethionine to a small

Table 1 The values of diffusion coefficients $\left(D_{o x}\right)$ of $1 \times 10^{-3} \mathrm{~mol} \mathrm{dm}^{-3} \mathrm{Bi}(\mathrm{III})$ ion electroreduction in $2 \mathrm{~mol} \mathrm{dm}^{-3}$ chlorates(VII) solutions of concentration ratio $\mathrm{HClO}_{4}: \mathrm{NaClO}_{4}:(1: 1)$ solution A, (1:4) solution B, (1:9) solution C, (4:1) solution D, (9:1) solution $\mathrm{E}$ and in the presence ethionine

\begin{tabular}{llllll}
\hline $10^{3} \mathrm{c}_{\text {ethionine }} / \mathrm{mol} \mathrm{dm}^{-3}$ & \multicolumn{1}{l}{$10^{6} \mathrm{D}_{o x} / \mathrm{cm}^{2} \mathrm{~s}^{-1}$} & & & \\
\cline { 2 - 6 } & $\mathrm{A}$ & $\mathrm{B}$ & $\mathrm{C}$ & $\mathrm{D}$ & $\mathrm{E}$ \\
\hline 0.00 & 5.09 & 4.56 & 5.13 & 6.22 & 4.92 \\
0.30 & 5.11 & 4.09 & 5.38 & 5.68 & 5.16 \\
1.00 & 4.94 & 4.21 & 4.69 & 5.57 & 5.19 \\
3.00 & 4.72 & 4.67 & 4.63 & 4.85 & 4.72 \\
6.00 & 5.06 & 4.11 & 4.39 & 5.05 & 4.14 \\
\hline
\end{tabular}

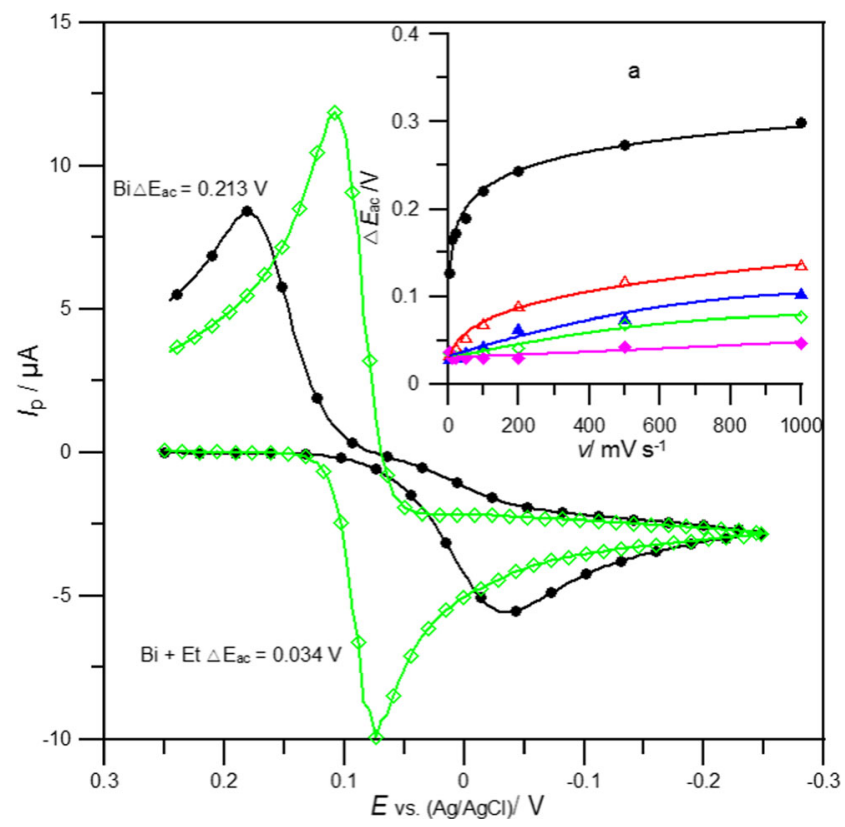

Fig. 3 The cyclic voltammograme of $1 \times 10^{-3} \mathrm{~mol} \mathrm{dm}^{-3} \mathrm{Bi}(\mathrm{III})$ in $2 \mathrm{~mol} \mathrm{dm}^{-3}$ chlorates(VII) $(\bullet)$ and in the presence $3 \times 10^{-3} \mathrm{~mol} \mathrm{dm}^{-3}$ ethionine $(\diamond)$, where $\mathrm{HClO}_{4}: \mathrm{NaClO}_{4}=1: 9(\mathrm{C})$. a The influence of polarisation rate on the difference between the potentials of the anodic and cathodic peaks for the $\mathrm{Bi}(\mathrm{III}) / \mathrm{Bi}(\mathrm{Hg})$ couple in $2 \mathrm{~mol} \mathrm{\textrm {dm } ^ { - 3 }}$ chlorates(VII) in the presence ethionine in $\mathrm{mol} \mathrm{dm}^{-3}: 0(\bullet), 3 \times 10^{-4}$ $(\Delta), 1 \times 10^{-3}(\boldsymbol{\Delta}), 3 \times 10^{-3}(\diamond), 6 \times 10^{-3}(\diamond)$; where $\mathrm{HClO}_{4}: \mathrm{NaClO}_{4}=1: 9(\mathrm{C})$

extent depends on the rate of electrode polarisation (Fig. 3a), which points to the chemical reaction controlling the

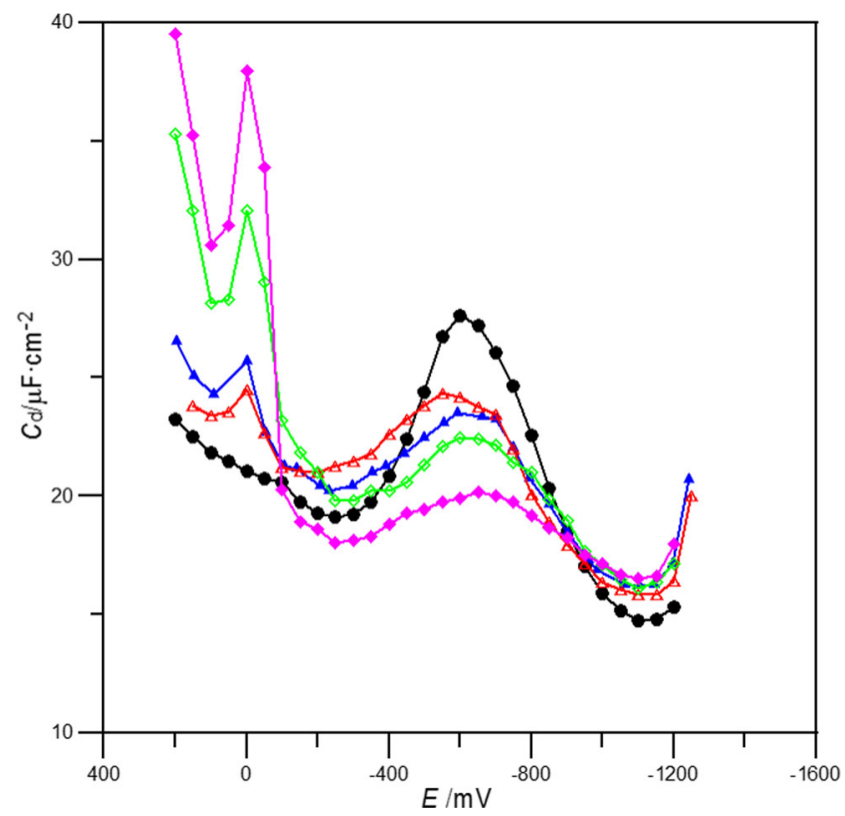

Fig. 4 Differential capacity - potential curves of double layer interface $\mathrm{Hg} / 6 \mathrm{~mol} \mathrm{dm}^{-3}$ chlorate (VII) in the presence ethionine in $\mathrm{mol} \mathrm{dm}^{-3}: 0(\bullet)$, $3 \times 10^{-4}(\Delta), 1 \times 10^{-3}(\Delta), 3 \times 10^{-3}(\diamond), 6 \times 10^{-3}(\diamond)$; where $\mathrm{HClO}_{4}: \mathrm{NaClO}_{4}=1: 4(\mathrm{~B})$ 
Table 2 Surface tension $\left(\gamma_{z}\right)$ for $\mathrm{E}_{\mathrm{z}}$ of $2 \mathrm{~mol} \mathrm{dm}^{-3}$ chlorates(VII) solutions of concentration ratio $\mathrm{HClO}_{4}: \mathrm{NaClO}_{4}:(1: 1)$ solution $\mathrm{A},(1: 4)$ solution $\mathrm{B},(1: 9)$ solution $\mathrm{C},(4: 1)$ solution $\mathrm{D},(9: 1)$ solution $\mathrm{E}$ and in the presence ethionine (in $\mathrm{mol} \mathrm{dm}{ }^{-3}$ )

\begin{tabular}{llllll}
\hline $2 \mathrm{~mol} \mathrm{dm}^{-3}$ chlorate(VII) & \multicolumn{4}{l}{$\gamma_{z} / \mathrm{m} \mathrm{N} \mathrm{m}^{-1}$} \\
\cline { 2 - 6 } & 0 & $3 \cdot 10^{-4}$ & $1 \cdot 10^{-3}$ & $3 \cdot 10^{-3}$ & $6 \cdot 10^{-3}$ \\
\hline A & 478.8 & 474.1 & 470.4 & 469.5 & 468.1 \\
B & 470.4 & 470.3 & 469.5 & 465.8 & 464.6 \\
C & 474.4 & 467.7 & 466.8 & 464.0 & 463.6 \\
D & 466.3 & 463.1 & 462.2 & 461.3 & 460.7 \\
E & 470.3 & 466.8 & 465.8 & 465.6 & 465.0 \\
\hline
\end{tabular}

electroreduction rate of $\mathrm{Bi}(\mathrm{III})$ ions in $2 \mathrm{~mol} \mathrm{dm}^{-3}$ chlorates(VII) in the presence of ethionine and in conditions of its varied protonation. The chemical reaction mentioned above is probably the $\mathrm{Bi}$-ethionine complex formation on the electrode surface, which is the intermediate during the electron transfer [4]. Such complexes were not observed in chlorate(VII) solutions using spectrophotometric methods. The formation of this complex is favoured by the ethionine adsorption on mercury.

The strong adsorptive properties of ethionine are reflected in the decrease in the differential volume in a fairly wide range of potentials (from $-200 \mathrm{mV}$ to approx. $-800 \mathrm{mV}$ ) in the area of a volume protuberance characteristic for chlorate(VII) solutions [20] (Fig. 4). In the area of more positive potentials (approx. $0 \mathrm{mV}$ ), after ethionine $(\mathrm{Et})$ is introduced in chlorate(VII) solutions, the effect of an increase in the differential volume associated with the appearance of the adsorption peak of the amino acid is observed. With an increase in the concentration of ethionine, the peak does not change its position significantly, but its height increases. The surface tension values (Table 2 ) at potential of zero charge $\gamma_{z}$ decrease, which also confirms the phenomenon of ethionine adsorption [21-25] on the electrode.

Therefore, it can be stipulated that active Bi(III)-ethionine complexes are certainly located inside the adsorptive layer (Fig. 5). It is similar to the previously studied influence of methionine on $\mathrm{Bi}(\mathrm{III})$ ions electroreduction [15].

\section{The Rate of Electroreduction}

On the basis of the parameter of cyclic voltammetry curves, the values of kinetic parameters were determined to indicate the catalytic effect of ethionine and its size (Table 3).

The use of electrochemical impedance spectroscopy enabled us to photograph the impedance spectrum at 26 frequencies in the range from 200 to $50,000 \mathrm{~Hz}$ within the faradaic potential region with $10 \mathrm{mV}$ intervals. This facilitated determination of activation polarisation resistances $\left(R_{A}\right)$ from the dependence $Z^{\prime}=f\left(\omega Z^{\prime \prime}\right)$ or $Z^{\prime}=f\left(Z^{\prime \prime}\right)$, where $Z^{\prime}$ is the real, and $Z^{\prime \prime}$ the imaginary, part of the cell impedance. From the charge transfer resistance values, the values of the apparent rate constant $\left(k_{f}\right)$ of $\mathrm{Bi}(\mathrm{III})$ electroreduction in chlorates(VII) in the presence of ethionine were obtained. The details are described elsewhere [14].

An increase in the concentration of ethionine in all the studied chlorate(VII) solutions has no significant effect on $E_{f}^{0}$ values (Table 3), which confirms the thesis that durable $\mathrm{Bi}(\mathrm{III})$ ions-ethionine complexes are not formed in the solutions.

An increase in the value of cathodic transition coefficients $\alpha$ after the introduction of ethionine in the basic electrolyte solution indicates an increase in reversibility of the Bi(III) ions
Fig. 5 The reaction path obtained for $\mathrm{Bi}$ (III) ion electroreduction showing active complexes $\mathrm{Bi}-$ ethionine acting as intermediates in electron transfer

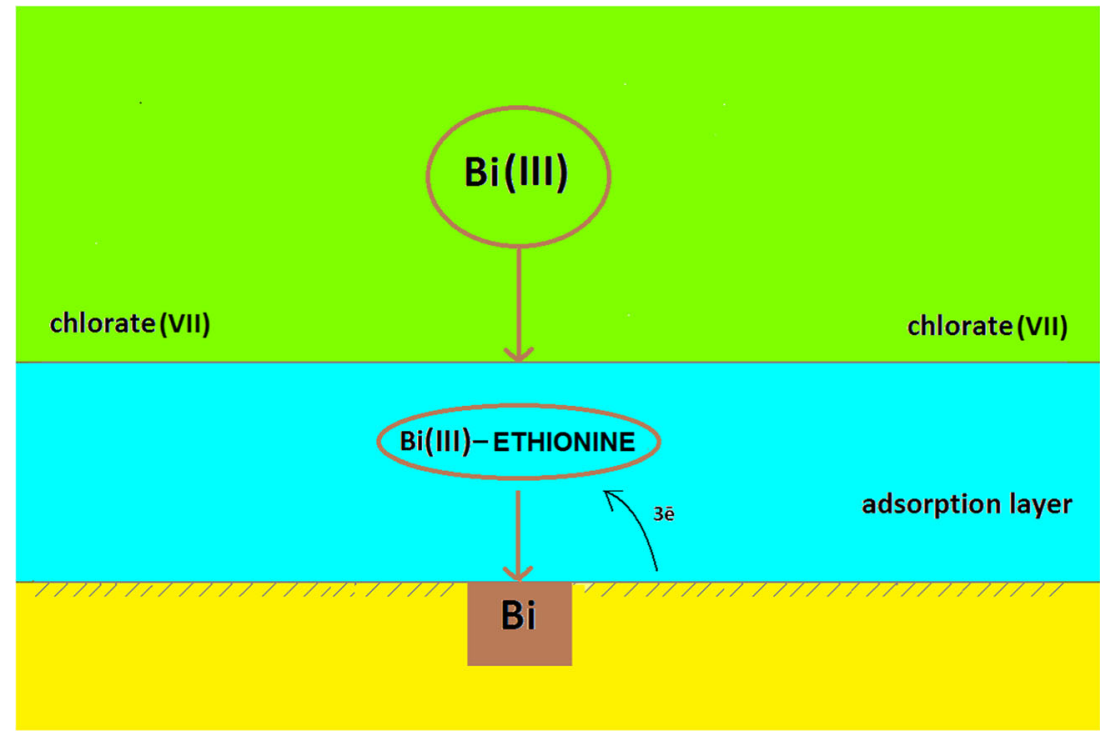


Table 3 The values of formal potentials $\left(E_{f}^{0}\right)$, cathodic transition coefficients $(\alpha)$, standard rate constants $\left(k_{S}\right)$ of electroreduction of $1 \times 10^{-3} \mathrm{~mol} \mathrm{dm}^{-3} \mathrm{Bi}(\mathrm{III})$ in chlorates(VII) solutions of concentration ratio $\mathrm{HClO}_{4}$ : $\mathrm{NaClO}_{4}:(1: 1)$ solution A, (1:4) solution $\mathrm{B},(1: 9)$ solution $\mathrm{C},(4: 1)$ solution D, (9:1) solution E [4] and in the presence $6 \times 10^{-3} \mathrm{~mol} \mathrm{dm}^{-3}$ ethionine

\begin{tabular}{|c|c|c|c|c|c|c|c|}
\hline \multirow{3}{*}{$\begin{array}{l}\text { Chlorate } \\
\text { (VII) }\end{array}$} & \multicolumn{7}{|c|}{$2 \mathrm{~mol} \mathrm{dm}^{-3}$} \\
\hline & \multicolumn{2}{|l|}{$\mathrm{E}_{\mathrm{f}}^{0} / \mathrm{V}$} & \multicolumn{2}{|l|}{$\alpha$} & \multicolumn{3}{|c|}{$10^{3} \mathrm{k}_{\mathrm{s}} / \mathrm{cm} \mathrm{s}^{-1}$} \\
\hline & $\mathrm{Bi}(\mathrm{III})$ & $\mathrm{Bi}(\mathrm{III})+\mathrm{Et}$ & $\mathrm{Bi}(\mathrm{III})$ & $\mathrm{Bi}(\mathrm{III})+\mathrm{Et}$ & $\mathrm{Bi}(\mathrm{III})$ & $\begin{array}{l}\mathrm{Bi}(\mathrm{III})+\mathrm{Et} \\
(\mathrm{CV})\end{array}$ & $\begin{array}{l}\mathrm{Bi}(\mathrm{III})+\mathrm{Et} \\
(\mathrm{EIS})\end{array}$ \\
\hline A & 0.102 & 0.085 & 0.28 & 0.60 & 0.143 & 5.64 & 6.10 \\
\hline B & 0.097 & 0.088 & 0.33 & 0.70 & 0.150 & 11.20 & 12.00 \\
\hline $\mathrm{C}$ & 0.095 & 0.088 & 0.35 & 0.81 & 0.152 & 12.20 & 14.40 \\
\hline $\mathrm{D}$ & 0.098 & 0.086 & 0.31 & 0.55 & 0.152 & 4.76 & 4.00 \\
\hline E & 0.102 & 0.080 & 0.27 & 0.57 & 0.128 & 4.17 & 3.84 \\
\hline
\end{tabular}

electroreduction. However, it has to be emphasised that this effect is significantly stronger for chlorate(VII) solutions in which the amount of sodium chlorate(VII) prevails in comparison to the amount of chloric(VII) acid (solution 2C).

The $k_{s}$ values confirm the catalytic effect of ethionine on Bi(III) ions electroreduction in $2 \mathrm{~mol} \mathrm{dm}^{-3}$ chlorates(VII) solutions. It should be noted that the values of the standard rate constants $k_{\mathrm{s}}$ determined from voltammetric measurements and from faradic impedance are in good agreement (Table 3). The catalytic activity of ethionine increases with increasing amounts of $\mathrm{NaClO}_{4}$ in the basic electrolyte solution. Increased amounts of $\mathrm{HClO}_{4}$ in chlorate(VII) solutions causes the decrease rate of the $\mathrm{Bi}$ (III) ion electroreduction process in the presence of ethionine. This confirms the assumption on the variety of active complexes mediating the passage of electrons [26]. Probably, the arrangement of the adsorbed ethionine on the surface of the mercury electrode, due to a change in the degree of ethionine protonation in basic electrolyte solutions, plays a significant role in the formation of active Bi-ethionine complexes, which are the substrate in the process of electroreduction. The non-linearity of the correlation $\ln k_{f}=$ $f(E)$ confirms the multi-step mechanism of $\mathrm{Bi}(\mathrm{III})$ ions electroreduction in all the studied chlorate(VII) solutions (Fig. 6a, b). Moreover, the effect of ethionine on the transfer of the first electron is significantly bigger than that on the transfer of other electrons. This might be connected with the formation of the aforementioned Bi-Et complexes as early as before the transfer of the first electron. This is the slowest stage, and it determines the speed of the whole process that was confirmed by Fawcett [27, 28] in their theoretical assumptions. Active complexes also participate in the transfer of further electrons. However, it has to be noted that the composition of active complexes changes after the transfer of successive electrons. a

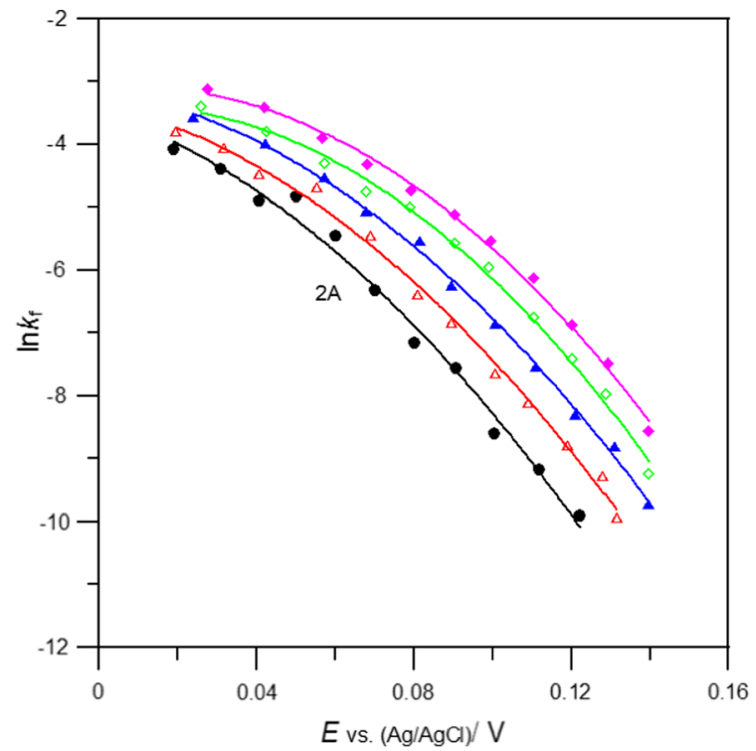

Fig. 6 a Dependence of the rate constants $k_{\mathrm{f}}$ of $1 \times 10^{-3} \mathrm{~mol} \mathrm{dm}{ }^{-3} \mathrm{Bi}(\mathrm{III})$ electroreduction in $2 \mathrm{~mol} \mathrm{dm}^{-3}$ chlorates(VII) in the presence ethionine in mol dm ${ }^{-3}: 0(\bullet), 3 \times 10^{-4}(\Delta), 1 \times 10^{-3}(\mathbf{\Delta}), 3 \times 10^{-3}(\diamond), 6 \times 10^{-3}(\diamond)$; where $\mathrm{HClO}_{4}: \mathrm{NaClO}_{4}=1: 1$ (A). b Dependence of the rate constants $k_{\mathrm{f}}$ of b

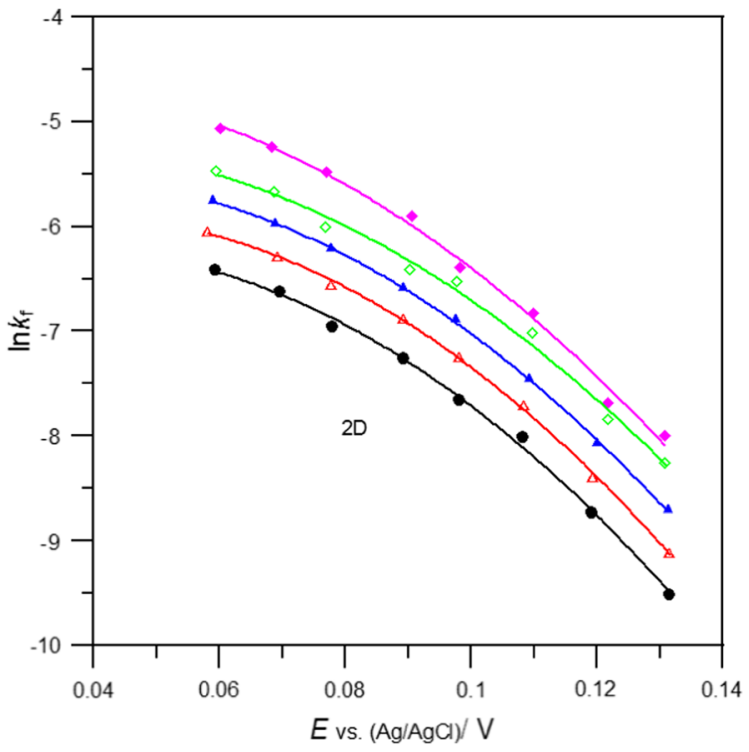

$1 \times 10^{-3} \mathrm{~mol} \mathrm{dm}^{-3} \mathrm{Bi}(\mathrm{III})$ electroreduction in $2 \mathrm{~mol} \mathrm{dm}^{-3}$ chlorates(VII) in the presence ethionine in mol dm${ }^{-3}: 0(\bullet), 3 \times 10^{-4}(\Delta), 1 \times 10^{-3}(\mathbf{\Delta})$, $3 \times 10^{-3}(\diamond), 6 \times 10^{-3}(\bullet)$; where $\mathrm{HClO}_{4}: \mathrm{NaClO}_{4}=1: 4(\mathrm{D})$ 


\section{Conclusions}

On the basis of the results of the voltammetry and impedance measurements and on the basis of the values of kinetic parameters, the following was determined:

- the catalytic effect of ethionine on the Bi(III) ions electroreduction in the $2 \mathrm{~mol} \mathrm{dm}^{-3}$ chlorates(VII) in conditions of varied protonation of the catalysing substance;

- the studied electrode process is a multi-step process;

- the mechanism of the catalytic effect of ethionine is associated with the formation of complexes in specific conditions which exist on the surface of the electrode;

- active Bi-ethionine complexes facilitate the exchange of electrons between $\mathrm{Bi}(\mathrm{III})$ ions and mercury during depolarisation;

- the highest catalytic activity of ethionine for the largest amount of $\mathrm{NaClO}_{4}$ (solution 2C);

- various properties of active complexes, due to the change in ethionine protonation, may be the cause of varied catalytic activity of the studied amino acid.

Open Access This article is distributed under the terms of the Creative Commons Attribution 4.0 International License (http:// creativecommons.org/licenses/by/4.0/), which permits unrestricted use, distribution, and reproduction in any medium, provided you give appropriate credit to the original author(s) and the source, provide a link to the Creative Commons license, and indicate if changes were made.

\section{References}

1. M.D. Johnson, J.F. Read, Inorg. Chem. 35, 6795 (1996)

2. F. Yoshizawa, S. Mochizuki, M. Doi, I. Yamaoka, K. Sugahara, Biosci. Biotechnol. Biochem. 73, 1984 (2009)
3. A. Nosal-Wiercińska, M. Grochowski, S. Skrzypek, D. Guziejewski, Desalin. Water Treat. 51, 1700 (2013)

4. A. Nosal-Wiercińska, Electroanalysis 26, 1013 (2014)

5. O. Ikeda, K. Watanabe, Y. Taniguchi, H. Tamura, Bull. Chem. Soc. Jpn. 57, 3363 (1984)

6. K. Sykut, G. Dalmata, J. Nieszporek, Electroanalysis 10, 458 (1998)

7. D. Gugała, Z. Fekner, D. Sieńko, J. Nieszporek, J. Saba, Electrochim. Acta 49, 2227 (2004)

8. J. Nieszporek, D. Gugała, D. Sieńko, Z. Fekner, J. Saba, Bull. Chem. Soc. Jpn. 77, 73 (2004)

9. G. Dalmata, Electroanalysis 17, 789 (2005)

10. J. Nieszporek, D. Gugała-Fekner, D. Sieńko, Z. Fekner, Collect. Czechoslov. Chem. Commun. 73, 616 (2008)

11. J. Nieszporek, J. Electroanal. Chem. 662, 407 (2011)

12. S. Komorsky-Lovrič, M. Lovrič, M. Branica, Indian J. Chem. 29A, 435 (1990)

13. S. Komorsky-Lovrič, M. Lovrič, M. Branica, J. Electrochem. Soc. 140, 1850 (1993)

14. A. Nosal-Wiercińska, Electrochim. Acta 55, 5917 (2010)

15. A. Nosal-Wiercińska, J. Electroanal. Chem. 654, 66 (2011)

16. A. Nosal-Wiercińska, J. Electroanal. Chem. 662, 298 (2011)

17. A. Nosal-Wiercińska, J. Electroanal. Chem. 681, 103 (2012)

18. M. Grochowski, A. Nosal-Wiercińska, M. Wiśniewska, A. Szabelska, B. Gołębiowska, Electrochim. Acta 201, 48 (2016)

19. M. Grochowski, A. Nosal-Wiercińska, J. Electroanal. Chem. 788, 198 (2017)

20. R. Parsons, R. Payne, Z. Phys, Chem. N. F. 98, 9 (1975)

21. A. Nosal-Wiercińska, G. Dalmata, Electroanalysis 22, 2081 (2010)

22. A. Nosal-Wiercińska, M. Grochowski, Collect. Czechoslov. Chem. Commun. 76, 265 (2011)

23. S. Chibowski, M. Wiśniewska, E. Opala Mazur, Powder Technol. 141, 12 (2004)

24. S. Chibowski, M. Wiśniewska, T. Urban, Adsorption 16, 321 (2010)

25. L. Bandura, R. Panek, M. Rotko, W. Franus, Microporous Mesoporous Mater. 223, 1 (2016)

26. A. Nosal-Wiercińska, Electrochim. Acta 92, 397 (2013)

27. W.R. Fawcett, J. Phys. Chem. 93, 2675 (1989)

28. W.R. Fawcett, J. Electroanal. Chem. 310, 13 (1991) 